\title{
AN ECONOMETRIC ANALYSIS OF CONSUMER DEMAND FOR COCONUTS IN SRI LANKA
}

By

\author{
S. R. Samarajeewa ${ }^{1}$
}

\begin{abstract}
This study analyses the domestic demand for coconuts in Sri Lanka using a single equation econometric model. The domestic coconut consumption accounts 70 percent of the total annual nut production in Sri Lanka. Being an essential commodity for household use, the coconuts form a stable domestic market out-let for producers as well. The results of the study reveals that the retail price of coconuts and per capita consumer income are significant variables that determine the quantity of coconut demand in Sri Lanka. There is a significant negative trend in per capita consumption of coconuts over time, indicating a declining tastes and preferences by the consumer. However, the changes in consumer demand for coconuts to the changes in retail prices are less responsive as indicated by the lower own price elasticity value of -0.11 . The income elasticity of coconut demand is 0.38 and it is inelastic too.
\end{abstract}

\footnotetext{
${ }^{1}$ Agricultural Economist, Coconut Research Institute, Bandirippuwa Estate, Lunuwila 61150, Sri Lanka
} 


\section{INTRODUCTION}

The coconuts became a commercially important plantation crop, in Sri Lanka during the Dutch and British colonial times and grew to be undeniably an important crop in the country's economy. The coconut sector has contributed $1.8 \%$ of the GDP in Sri Lanka during the year 2000, in terms of employments, income generations, and foreign exchange earnings etc (Central Bank of Sri Lanka, 2000).

The total annual coconut production in the island ranges from 2000 to 3000 million nuts, depending on the lagged effect of weather, cultural and management practices. The uses of coconuts are diverse in Sri Lanka. It provides a base for the emergence of various industrial uses than any other agricultural crop grown in the country. However, the domestic coconut consumption is a priority, and utilizes 65 to 70 percent of the total annual nut production. The rest 30 to 35 percent of the production is used in many other coconut based agro industries for the production of range of coconut-based value added products such as desiccated coconut, copra, coconut oil, cream and milk powder etc. both for domestic and export market.

The average annual per capita consumption of coconuts in Sri Lanka is about 110 nuts and it is considerably a higher number of nuts than any other coconut producing country in the world. The fresh coconuts have become a daily necessity for the people in the country for over thousands of years. The most important use of coconuts is to extract coconut milk in fresh form and utilize as a basic ingredient in domestic culinary preparations. The coconut oil, which 
is extracted from the dried kernels, is also an important constituent in various traditional Sri Lankan dishes. The other forms of coconut consumption comprise coconut based household products like confectionaries, detergents, cosmetics etc.

Coconut is the principle source of dietary fat for average Sri Lankan people. The contribution of coconuts to calories in diet is second only to rice; the staple diet in Sri Lanka. Coconuts and coconut oil add 17.4 percent of calories, 7 percent of protein and 79.4 percent of the fats in average daily diet of a Sri Lankan (Perera, 1990). The highest per capita consumption of coconuts as fresh nuts is observed in the rural sector of the country, consuming around 100 fresh coconuts per head per year (Central Bank of Sri Lanka, 1996). Hence, the coconuts are one of the cheap sources of food nutrition especially for the poor people in the country.

The role of fresh coconuts, coconut oil and other coconutbased products in diet is one of the most important advantages of the domestic coconut sector forming a stable market out let for the producers. The marketable surplus of coconuts is accounted to be 84 percent of the total production, leaving 16 percent of the production for on-farm consumption (Perera, 1990). The Sri Lankan consumers spend 9 percent of their total food budget on fresh coconuts and coconut oil (Central Bank of Sri Lanka, 1997). Accordingly, coconuts and coconut oil have become the third most important food item in the consumer's food budget followed by rice and fish expenditures. The price for coconuts is largely determined based on the domestic market forces depending on the production and consumption levels. The total coconut demand shows a slow steady 
upward trend over the years with the increasing population. However, the annual coconut supply tends to be fluctuating widely based on the lagged weather pattern and other supply influencing factors.

During the last two decades the food consumption patterns observed in Sri Lanka have been changing gradually. Forces responsible for shaping the demand for food are varied. They include not only the economic and demographic factors but also changes in lifestyles, which influence consumers' tastes and preferences. Despite, the coconut is considered as an essential food commodity in Sri Lanka and subsequently makes a strong domestic demand; the coconut consumers' responses to the changes in the economic and other non-economic variables are yet to be determined. The understanding of the coconut consumers' responses for different demand influencing factors provides guidance on effective policy formulation for the coconut sector. Therefore, the objectives of this study are to identify the major factors influencing the demand for coconuts in Sri Lanka and to estimate the elasticity of demand for coconuts with respect to price and income variables.

\section{AMPIRICAL MODEL}

Demand is a behavioural relationship that describes how much product will be purchased at different prices under a carefully designed set of conditions. Consumer demand refers to the purchasing behaviour of one or more buyers who will consume the utility of a product subjected to his budget constraint. The market or the aggregate demand for a consumer good is the sum of all consumer demands at given prices in a particular time period. 
Economic theory suggests that the important economic factors, which influence the demand for a particular commodity, are consumer per capita income and the price of that commodity relative to its complements and substitute goods. When the price of a commodity is low the consumer tends to buy more and thus there is an inverse relationship between the price of a commodity and its level of consumption. When the consumers' income is high the consumer tends to buy more and thus there is a positive relationship between the consumer income and the consumption level.

The retail price of coconuts may play a substantial role in consumers' choices, though there are no close substitutes available for fresh coconuts in Sri Lanka. The effect of income growth on food expenditures depends on income elasticity of demand, which measures the effect of changes in demand with respect to the income changes. However, the non-economic factors such as dietary concerns, changes in tastes and preferences etc. can offset the effect of economic factors on food consumption. Based on these facts, the coconut demand was specified as a function of its own retail price, disposable personal income, and the time trend. A trend variable was introduced into the model to reflect the changes in consumers' tastes and preferences towards the coconuts.

The general form of the fresh coconut demand model is as follows;

$$
\mathrm{Q}_{\mathrm{t}}=?_{0}-?_{1} \cdot \mathrm{P}_{\mathrm{t}}+?_{2} \cdot \mathrm{I}_{\mathrm{t}}+?_{3} \cdot \mathrm{T}_{\mathrm{t}}
$$

Where, $Q$ represents per capita coconut consumption in number of nuts in time period $t, P_{t}$ is the retail price of fresh coconuts in rupees per nut in time period $t, I_{t}$ is per capita disposable income in rupees 
in time period $t$, and $T_{t}$ is the trend factor $(1,2,3 \ldots)$. The "?" are the parameters to be estimated. All the price and income variables were deflated using the Colombo Consumer Price Index numbers (Department of Census \& Statistics, Sri Lanka) to remove the inflation effect. The annual data for these variables were collected from the annual statistical publications of the Coconut Development Authority, Department of Census and Statistics and the Central Bank of Sri Lanka. The parameters of the specified model were then estimated using Ordinary Least squares (OLSQ) method (Gujarati, 1995) for the period of 1970 - 2000. As the initial estimation diagnosed an autocorrelation problem, the model was re-estimated using first order auto regression technique to generate consistent results.

\section{RESULTS AND DISCUSSION}

The linear model showed the best fit with the data and selected as appropriate for further inferences. Results of the estimation of the fresh coconut demand function are presented in Table 1 . The goodness of fit value of the model was 0.83 , indicating that more than 83 percent of the variability in the quantity of domestic demand of coconuts was explained by the model. Overall, the demand model was consistent with the economic theory generating correct signs for the relevant variables. The own retail price and income coefficients were significant at 5 percent significance level. Since the linear function was estimated, the elasticity values were calculated at the mean values of the variables over the thirty-year data period and present in Table 2. 
The estimated results revealed that the retail price of coconuts is a significant variable, which alters the individual consumer's demand schedule and subsequently determines the aggregate quantity of coconut demand in Sri Lanka. The own price elasticity of coconut demand was calculated as -0.11 and it is a highly inelastic value closer to zero. The price elasticity of demand for a commodity depends mainly on the range of available substitutes. The better the substitutes available, the more elastic will be the demand for the commodity and vice versa. The own price elasticity value for coconuts implies that for a one percent change in retail price of coconuts, the consumer changes his demand only by 0.1 percent. The implication is that the coconut consumers do not reduce their coconut consumption in a notable amount in case of a price increase. This suggests the coconut is an essential food commodity for the people in Sri Lanka. The consumer has no opportunity to shift his preferences according to the changing coconut price levels, as there are no close substitutes available for him. Therefore, increase in retail prices of coconuts reduces the quantity of coconut demand by an insignificant quantity. Hence, a slight increase in fresh coconut retail price adversely influences on fresh coconut consumers. In contrast a slight increase in the fresh coconut price is largely beneficial to the producer if the marketing channels are efficient or else to the intermediaries. Consequently, it increases either coconut producers' or intermediaries' incomes at the expense of the coconut consumer. 
Table 1. Results of the Econometric Estimation

\begin{tabular}{lcccc}
\hline Variable & & $\begin{array}{c}\text { Estimated } \\
\text { coefficient }\end{array}$ & 't' value & 'p' value \\
\hline Constant & $?_{0}$ & 110.9 & 10.24 & 0.000 \\
Own retail price & $?_{1}$ & $-3664.2 * *$ & -3.88 & 0.000 \\
Per capita income & $?_{2}$ & $3.01 * *$ & 2.00 & 0.045 \\
Trend & $?_{3}$ & $-1.71 * *$ & -2.34 & 0.019 \\
\hline
\end{tabular}

$\mathrm{R}^{2}=0.83$, Adjusted $\mathrm{R}^{2}=0.81 \quad \mathrm{DW}=1.89$

** Significant at $5 \%$ level

Table 2. Estimated Elasticity Values of Coconut Demand In Sri Lanka

\begin{tabular}{lc}
\hline & Elasticity value \\
\hline Own price & $-0.11 * *$ \\
& $(-3.88)$ \\
Income & $+0.38 * *$ \\
& $(2.00)$ \\
\hline
\end{tabular}

Sample period-1970-2000

Figures in parenthesis are the ' $\mathrm{t}$ ' values

** Significant at $5 \%$ level

Since, the coconut is highly a weather responsive crop, there are wide fluctuations of its yielding pattern through out the year. There are surpluses in supplies of coconuts during the May-July period while there are shortages during the December-February 
period depending on the prevailing weather pattern in Sri Lanka. Therefore, the short supply of coconuts in the market with subsequent price increases greatly affects the coconut consumers in the country. Always, there are more numbers of coconut consumers in the market than the number of coconut producers. Since, the coconut is the third most important food commodity expenditure for the average consumer in Sri Lanka, any increases in coconut price directly influences the cost of living indices. In this regard, the policy measures, which address the consumer interests, are more important to ensure a reasonable retail price for coconuts in the domestic market throughout the year.

The estimated results revealed that the consumer's per capita income was also a significant variable, which determines the demand for coconuts in Sri Lanka. The income elasticity of coconut demand was calculated as 0.38 , implying that for a one percent increase in consumer's income; the coconut demand increases by 0.38 percent. Thus the coconut behaves as a normal good for the consumer, where the demand rises when the consumer's incomes rises. The coconut demand appears substantially more responsive to the changes in the per capita income, than that of own retail price as indicated by the magnitudes of the values of price and income elasticity of coconut demand. As a result, increase in consumers' per capita income has favourable impact on expanding the coconut consumption in Sri Lanka. This can be further justified by the results revealed by the consumer finance and socio economic survey carried out by the Central Bank of Sri Lanka during the 1996/97 periods. The survey has revealed, beyond the monthly income threshold of Sri Lankan Rupees 1200 , the coconut consumption increases with income, for all 
the other income classes irrespective of the urban, rural or estate sectors in the country. Therefore, the real economic growth of the country positively contributes to enhance the national coconut demand and thereby to enhance the coconut producers' incomes as well.

The estimated coefficient for the trend variable, which was used as the proxy to indicate coconut consumers' tastes and preferences, was negative and significant at 5 percent level. Surprisingly, the sign and the significance of the coefficient reflected the declining tastes and preferences for coconuts by the Sri Lankan consumers over the years. Tastes are generally affected by advertising, by fashion, by observing other consumers, by considering health and by the experiences from consuming the good on previous occasions etc. According to the findings of the recent consumer finance survey in 96/97 by the Central Bank of Sri Lanka, the food consumption pattern of the people in the country has changed over the years due to several factors. These factors include changes in consumer preferences, relative price variations, changing demographic composition, policy measures and variations in supply conditions etc. The findings of the above survey point out that the fresh coconut consumption has increased only in the rural sector by 1.2 percent, stagnant in the estate sector and has decreased by 7.2 percent in the urban sector compared to the previous survey, which has been conducted during 1986/87 period (Central Bank of Sri Lanka, 1997). Based on these findings, there is a considerable declining trend in coconut consumption in the urban sector. The expansion of the urban boundaries, and the rapid movement of people into these areas possibly make a net result of declining of per capita 
coconut consumption, which can offset the incremental consumption trend in the rural sector of the country. However, the result of this study regarding the trends in coconut consumption is consistent with the declining trend observed in the urban sector of the country.

Apparently, the urban consumers are more likely to concern on the dietary factors and hence on the food composition, guided by their customary life styles. Moving away from dietary fat and oil consumption is a common phenomenon associated among modern health conscious urban communities. Incidentally, the coconuts comprise high fat content. Therefore this could be considered as a negative indicator for coconut consumption, especially by the urban consumers of the country. In addition, with rapid urbanization and increase in income levels, people tend to use electrically operated household equipments such as liquidizers, grinding machines etc. for the extraction of coconut milk for daily food preparations. These equipments can easily and efficiently extract coconut milk and thereby reducing the total number of coconuts to be consumed by an individual. Despite of these factors, the propaganda which links the blood cholesterol and the coconut oil consumption might have created adverse impacts on the quantity of coconut intakes and that too can be reflected in the declining trend in the total coconut consumption. Sometimes these non-economic factors can offset the impacts of economic variables on domestic coconut consumption. However further studies are needed in this regard, to make precise conclusions on declining trends in per capita coconut consumption. 


\section{CONCLUSION}

Based on the analysis of annual data for the period 1970 to 2000, the coconut demand in Sri Lanka is found to be significantly influenced by the retail coconut prices and the consumer's per capita income, and the changes in the tastes and preferences of the consumers. The empirical results of the study showed the domestic demand for coconuts to be inelastic over a wide range of retail prices. The own price elasticity was calculated as -0.11 and it implies the coconut consumers are less responsive to retail price changes, as it is an essential food commodity for household consumption without a closer substitute. The estimated response to income shows coconut to be a normal good. The income elasticity of coconut demand was 0.38 , indicating the income effect is substantially higher than that of the own price effect. Therefore, increase in per capita income will create a better demand for coconuts in the country. The results revealed that there is a significant decreasing trend in the per capita coconut consumption in the country over the years. This can be attributed by other non-economic factors like urbanization, variations in food preparation methods and composition of food intake associated with health consciousness etc. This study provides a preliminary perspective on the aggregate market demand for coconuts in Sri Lanka. The estimated price and income elasticity values can be productively used in future income and price policy formulations regarding the coconut sector in Sri Lanka. 


\section{REFERENCES}

Central Bank of Sri Lanka. (2000). Annual Report. Colombo. Sri Lanka.

Central Bank of Sri Lanka. (1997). Report of the Consumer Finance and Socio Economic Survey 1996/1997. Colombo. Sri Lanka.

Department of Census \& Statistics. Annual Statistical Abstracts (various issues). Colombo. Sri Lanka.

Damodar N Gujarati. (1995). Basic Econometrics. $3^{\text {rd }}$ Ed. McGraw Hill Inc.

Perera. U.V.H. (1990). Coconut Industry in Sri Lanka. Occasional Publication series. No.10. Asian \& pacific Coconut Community. Jakarta. Indonesia. 